\title{
Requests for Information in Class Actions
}

Class action suits, long a problem for the courts under old Rule 23, have once again become embroiled in judicial controversy. The disagreement centers around the extent to which class members in 23 (b)(3) suits ${ }^{1}$ can be required, ${ }^{2}$ if at all, ${ }^{3}$ to furnish information

1. A suit is maintainable as a class action under FED. R. Crv. P. 23(b)(3) if the court finds that common questions of law or fact predominate and the class action is the superior method of adjudication; under 23(b)(2) if injunctive or declaratory relief is sought "with respect to the class as a whole"; or under 23(b)(1) if the prosecution of separate actions by or against individual members of the class would create a risk of inconsistent or varying adjudications. The question of requiring information or affirmative action from absent class members has arisen only in (b)(3) class actions. In suits maintainable as class actions under (b)(1) or (b)(2) the entire class is necessarily bound by the judgment. Class members cannot opt out of the action as they can in

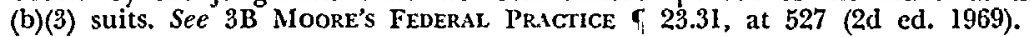

2. A number of courts have held that class members must take some affirmative action in order to be included in the judgment. See Brennan v. Midwestern United Life Ins. Co., 450 F.2d 999 (7th Cir. 1971), cert. denied sub nom. Herriman v. Midwestern United Life Ins. Co., 405 U.S. 921 (1972); Bicchele v. Norfolk \& W. Ry., 309 F. Supp. 354, 356 (N.D. Ohio 1969); Iowa v. Union Asphalt \& Roadoils, Inc., 281 F. Supp. 391 (S.D. Iowa 1968); Minnesota v. United States Steel Corp., 44 F.R.D. 599 (D. Minn. 1968); Philadelphia Electric Co. v. Anaconda Amer. Brass Co., 43 F.R.D. 452 (E.D. Pa. 1968) (with respect to the class of government entities); Harris $v$. Jones, 41 F.R.D. 70 (D. Utah 1966). See also 3B Moore's Federal Pracrice 23.55 , at 1161 (2d ed. 1969), approving this practice; and $7 \mathrm{~A}$ C. WRIGHT \& $A$. Miller, Federal Prictice \& Procedure \& 1792, at $196 \mathrm{n} .96$ (1972) [hereinafter cited as Wright \& Mill.er], agreeing that discovery is available against absent class members; cf. Quinault Allottec Iss'n v. United States, 453 F.2d 1272 (Ct. Cl. 1972), where the Court of Claims requircd class members to exclude themselves and to take affirmative action for inclusion. The Court of Claims is not compelled to follow the Federal Rules of Civil Procedure and had not adopted a rule equivalent to Rule 23 , although it borrowed some concepts from the federal rule.

3. Courts rejecting the practice of compelling information of absent class members before trial fall into two categorics: those which request information but refuse to penalize inaction and those which refuse to impose any affirmative duties or requirements. Cases in which courts requested information but refused to apply penalties include Arey v. Providence Hospital, 55 F.R.D. 62, 72 (D.D.C. 1972); Abulaban v. R.W. Pressprich \& Co., 51 F.R.D. 496 (S.D.N.Y. 1971); and Korn v. Franchard, 50 F.R.D. 57, 60, class action designation withdrawn, [1970-71 Transfer Binder] CCH Fed. SEC. L. REP. T 92,845 (S.D.N.Y. 1970), rev'd, 456 F.2d 1206 (2d Cir. 1972). The court in Abulaban noted that "[f]ailure to file any document in the nature of an inclusionary request should not, in the initial stages of the litigation, preclude a person from being considered a member of the class." However, the court agreed to include a form of request for exclusion from the class along with notice. 51 F.R.D. at 497.

Cases in which courts refused to impose any duties on absent class members include Gardner v. Awards Marketing Corp., 55 F.R.D. 460 (D. Utah 1972); Fischer v. Wolfinbarger, 55 F.R.D. 129 (W.D. Ky. 1971); Wainwright v. Kraftco Corp., 54 F.R.D. 532 (N.D. Ga. 1972); Berman v. Naragansett Racing Ass'n, 48 F.R.D. 333 (D.R.I. 1969); Kronenburg v. Hotel Governor Clinton, Inc., 281 F. Supp. 622, 625 (S.D.N.Y. 1967); and the coordinated pretrial proceedings in In re Antibiotic Antitrust Actions, $333 \mathrm{~F}$. Supp. 267, 271 (S.D.N.Y. 1971); 333 F. Supp. 278, 279-82 (S.D.N.Y. 1971), wherein the court required proofs of claim from the government entities within each state but refused to require proofs of claim from absent individual class members prior to trial, particularly since such class members were unlikely to have individual claims large enough to justify 
before trial to the court or to the defendant as a condition to participation in class recoveries, and what sanctions may be imposed for noncompliance. On its face, the new Rule 23 does not explicitly authorize any discovery of class members, yet some courts have not only required such discovery, but have also dismissed or threatened to dismiss with prejudice the claims of nonresponding class members. ${ }^{4}$ Courts taking this general position have failed to articulate an acceptable standard for determining when information is warranted. There is thus the danger that discovery may be too easily granted and the particular sanction imposed may be unjustifiable in light of the basic purposes of a class action suit.

On the other hand, situations conceivably exist where a carefully policed discovery or request for information by the court, possibly with limited penalties, is appropriate. Courts may be justified in giving the class action rule a broader reading than its language apparently calls for when justice or manageability so requires. Courts should be extremely hesitant, however, to resort to the drastic measure of dismissal with prejudice to enforce such efforts, particularly since milder steps which achieve the same degree of manageability and fairness exist.

\section{The Language of the Rules}

Relying on the Federal Rules for discovery ${ }^{5}$ or an implied authority in Rule 23 , some courts have required absent class members to file, before trial, actual claims, ${ }^{6}$ statements of intent to submit

the expense of executing a proof-of-claim form until they were assured of recovery. In Gardner, the court refused to allow the defendants to pose interrogatories to class members on the ground that they were "unnecessary and unjustifiably dilatory" despite the fact that the defendant sought no penalty. Nonetheless, the court maintained that courts had the discretionary power to "allow the submissions of interrogatories to the members of the class at an appropriate time and for essential purposes." 55 F.R.D. at 462.

4. Brennan v. Midwestern United Life Ins. Co., 450 F.2d 999 ("7th Cir. 1971); Iowa v. Union Asphalt \& Roadoils, Inc., 281 F. Supp. 391, 403-04 (S.D. Iowa 1968); Philadelphia Electric Co. v. Anaconda Amer. Brass Co., 43 F.R.D. 452, 462 (E.D. Pa. 1968); Harris v. Jones, 41 F.R.D. 70, 75 (D. Utah 1966). In Minnesota v. United States Steel Corp., 44 F.R.D. 559, 577 (D. Minn. 1968), the court suggested that nonresponding class members would be "barred and excluded from the classes." This wording is ambiguous. The court may have intended to dismiss with prejudice; however, another court viewed the action as an exclusion without prejudice. See Brennan v. Midwestern United Life Ins. Co., supra at 1004 n.2.

5. FED. R. CIV. P. 33, 34, 37.

6. Minnesota v. United States Steel Corp., 44 F.R.D. 559, 577 (D. Minn. 1968) (requiring the execution of a proof of claim form, with detailed information about purchases); Harris v. Jones, 41 F.R.D. 70, 74 (D. Utah 1966) (requiring "simple statements of . claims ... particularly with reference to the types and sources of representation, if any, upon which they relied in purchasing their securities and the time they first learned any representations were false"). 
claims, ${ }^{7}$ statements of intent to prove damages, ${ }^{8}$ detailed claim information, ${ }^{9}$ and sometimes information on representation and reliance. ${ }^{10}$ These requirements, often in the nature of discovery, conflict with the language and to some extent the policy of the class action rule.

Theoretically, the discovery rules enable one party to obtain information from another, whereas Rule 23 procedures enable the court to conduct a class action suit. However, courts have not adhered to this strict doctrinal distinction. Instead, both rules have been cited as authority for court orders penalizing unresponsive class members. The cases seem largely to ignore whether a party or the court is seeking the information; ${ }^{11}$ indeed, sometimes the defendants have urged the courts to require affirmative action from absent class members under the authority of Rule $23 .^{12}$ Requirements to supply information or face significant penalties under the purported authority of either Rule 23 or 37 have the same effect on class members. Distinctions between the two rules have thus been blurred and both have emerged as authority for requiring discovery-like information of absent class members.

7. Iowa v. Union Asphalt \& Roadoils, Inc., 281 F. Supp. 391, 404 (S.D. Iowa 1968) (stating that failure of the absent class members to so act before trial would completely bar any future recovery should the defendant be subsequently held liable on the cause of action).

8. Philadelphia Electric Co. v. Anaconda Amer. Brass Co., 43 F.R.D. 452, 459, 462 (E.D. Pa. 1968) (the court suggested that it was reasonable to bar the claims of passive class members unless they filed a statement of their intent to prove damages; it notified members of the government class to file actual proofs of claim or be "forever barred.").

9. Brennan v. Midwestern United Life Ins. Co., 450 F.2d 999, 1004-05 (7th Cir. 1971); Minnesota v. United States Steel Corp., 44 F.R.D. 559, 577 (D. Minn. 1968).

10. Brennan v. Midwestern United Life Ins. Co., 450 F.2d 999, 1004.05 (ith Cir. 1971). A list of defendant's interrogatories to plaintiffs is printed in the Appendix to Appellant's Brief at 55 , Harris v. Jones, 41 F.R.D. 70 (D. Utah 1966).

11. In Brennan v. Midwestern United Life Ins. Co., 450 F.2d 999 (7th Cir. 1971), the court cited the discovery rules (Rules 33, 34, and 37) and Rulc 23 as authority for requiring absent class members to answer defendant's interrogatories, $i d$. at 1004-05, or be dismissed with prejudice, id. at 1006. In Iowa v. Union Asphalt \& Roadoils, Inc., 281 F. Supp. 391, 403-04 (S.D. Iowa 1968), the court cited Rule 23 as authority for granting defendant's request that class members be required to acknowledge in writing their intent to submit claims or be barred from any recovery. Nithough the de. fendant moved for such a requirement, the court also sought the information in the interest of "expediency." Id. at 404.

Nor have the courts distinguished between information required by the court and information required by another party in the cases they cite as authority for the practice. For example, the Brennan court, $450 \mathrm{~F} .2 \mathrm{~d}$ at 1004, cited Minnesota v. United States Steel Corp., 44 F.R.D. 559 (D. Minn. 1968); Philadelphia Electric Co. v. Anaconda Amer. Brass Co., 43 F.R.D. 452 (E.D. Pa. 1968); and Harris v. Jones, 41 F.R.D. 70 (D. Utah 1966), as authorities for the principle that "some form of discovery may be required of class members." However, Brennan was a case in which the opposing parties sought discovery of class members, while the authorities cited were.cases in which the court itself apparently sought the information.

12. See Abulaban v. R.W. Pressprich \& Co., 5I F.R.D. 496, 496.97 (S.D.N.Y. 1971); Iowa v. Union Asphalt \& Roadoils, Inc., 281 F. Supp. 391, 403-01 (S.D. Iowa 1968). See generally Korn v. Franchard, 50 F.R.D. 57 (S.D.N.Y. 1970). 


\section{A. Rule 37}

Rule $37(b)(2)(c)$ allows a court to dismiss an action or render a judgment by default against a disobedient party for failure to comply with discovery requirements. ${ }^{13}$ Since the rule gives the court control only over "parties" and their agents, dispute has focused on the status of absent class members. Apparently assuming absent class members are parties and subject to discovery, one court has used this rule to dismiss with prejudice the claims of those members who failed to respond, ${ }^{14}$ while other courts have held that absent class members were not parties and could not be subject to discovery. ${ }^{15}$

Rule 37 was not changed when Rule 23 was revised; its original draftsmen did not contemplate the problems of discovery from absent class members. Nor does the 1970 revision of Rule 37 indicate a consciousness of this issue. ${ }^{16}$ Thus, this rule provides no insight as to whether absent class members are parties subject to discovery. Nor have the courts dealt satisfactorily with the question of party status. Although some have suggested that only named plaintiffs are parties, ${ }^{17}$ all of the courts discussing party status ultimately have based their arguments on the spirit and purpose of the class action rule. ${ }^{1 s}$ Thus, to call a person a party or not is merely to state a conclusion;

13. FED. R. CIv. P. 37(b) provides in relevant part:

(2) Sanctions by court in which action is pending. If a party or an officer, director, or managing agent of a party or person designated under Rule $30(\mathrm{~b})(6)$ or 31 (a) to testify on behalf of a party fails to obey an order to provide or permit discovery, including an order made under subdivision (a) of this rule or Rule 35 , the court in which the action is pending may make such orders in regard to the failure as are just, and among others the following:

-...

(C) An order striking ont pleadings or parts thereof, or staying further proceedings until the order is obeyed, or dismissing the action or proceeding or any part thereof, or rendering a judgment by default against the disobedient party; . . .

14. Order of Eschbach, J., dated Aug. 17, 1967, set out in Appendix to Brief for Appellants at 70, Brennan v. Midwestern United Life Ins. Co., 450 F.2d 999 (7th Cir. 1971). See also Brennan, 450 F.2d at 1004-05. The Brennan court refers at one point to absent class members as "absent parties." Id. at 1005.

15. See Wainwright v. Kraftco Corp., 54 F.R.D. 532, 534 (N.D. Ga. 1972); Fischer v. Wolfinbarger, 55 F.R.D. I29, 132 (W.D. Ky. 1971). See also Bucalo v. General Leisure Prods. Corp., 15 Fed. Rures SERv. 2d 564, 566 (S.D.N.Y. 1971), wherein the court refused to allow the named plaintiff in a class action to withdraw as representative of the class and become merely a member of the class, noting that he would then not be subject to discovery.

16. See FED. R. Civ. P. 37, Advisory Commiltee's Nole (1970 Amendment), at 306-10 (Foundation Press ed. 1970).

17. Wainwright v. Kraftco Corp., 54 F.R.D. 532, 534 (N.D. Ga. 1972); Fischer v. Wolfinbarger, 55 F.R.D. I29, 132 (W.D. Ky. 1971); cf. Donson Stores, Inc. v. American Bakeries Co., 58 F.R.D. 485 (S.D.N.Y. 1973).

18. See Brennan v. Midwestern United Life Ins. Co., 450 F.2d 999, 1004-05 (7th Cir. 1971): Wainwright v. Kraftco Corp., 54 F.R.D. 532, 534 (N.D. Ga. 1972); Fischer v. Woltinbarger, 55 F.R.D. 129,132 (W.D. Ky. 1971); cf. Donson Stores, Inc. v. American Bakeries Co., 58 F.R.D. 485 (S.D.N.Y. 1973). 
the question is whether absent class members should be subject to discovery, and, if so, under what conditions. ${ }^{19}$

\section{B. Rule 23}

Courts have invoked subdivisions (c)(2) and (d) of Rule 23 as authority for their imposition of duties and sanctions on class members who do not respond to requests for information..$^{20}$ Neither provision, however, justifies these results. Subdivision (c)(2) merely enables the court to notify class members in a (b)(3) suit that they will be included unless they request not to be. This is the only function

19. For example, in Brennan, $450 \mathrm{~F} .2 \mathrm{~d}$ at 1004 , the court acknowledged that the "party" question "is a difficult onc," admitting that "there is some merit" in the argument that absent class members, not being partics in any ordinary sense, are not subject to discovery. The court did not directly answer that argument, obscrving that "under certain circumstances" Rule 37 penalties may be imposed to compel compliance with discovery orders. Id. And in Fischer v. Wolfinbarger, 55 F.R.D. at 132, the court reasoned that discovery proceedings directed to members of the class who are not named plaintiffs are improper. Noting that the class action is designed for the situation in which joinder of all members of a class is impracticable, the court concluded that "[i]t is not intended that members of the class should be treated as if they weic parties plaintiff, subject to the normal discovery procedure, because if that were permitted, then the reason for the rule would fail." Id.

The courts have been unable to apply a meaningful test to determine whether absent class members are parties because no definitive test is available. In suits other than class actions "parties" are simply the persons bringing or defending the lawsuit or are intervenors. The question thus ariscs only in connection with class suits.

20. FED. R. Civ. P. 23(c)(2) provides:

In any class action maintained under subdivision (b)(3), the court shall direct to the members of the class the best notice practicable under the circumstances, including individual notice to all members who can be identified through reason. able effort. The notice shall advise each member that (A) the court will cxclude him from the class if he so requests by a specificd date; (B) the judgment, whether favorable or not, will include all members who do not request exclusion; and (C) any member who does not request exclusion may, if he desires, enter an appearance through his counsel.

FED. R. Civ. P. 23(d) provides:

In the conduct of actions to which this rule applies, the court may make appropriate orders: (1) determining the course of proceedings or prescribing measures to prevent undue repetition or complication in the presentation of evidence or argument; (2) requiring, for the protection of the members of the class or otherwise for the fair conduct of the action, that notice be given in such manner as the court may direct to some or all of the members of any step in the action, or of the proposed extent of the judgment, or of the opportunity of members to signify whether they consider the representation fair and adequate, to intervene and present claims or defenses, or otherwisc to come into the action; (3) imposing conditions on the representative parties or on intervenors; (4) requiring that the pleadings be amended to eliminate therefrom allegations as to representation of absent persons, and that the action proceed accordingly; (5) dealing with similar procedural matters. The orders may be combined with an order under Rule 16, and may be altered or amended as may be desirable from time to timc. Of the courts relying on Rule 23 for authority, the following cited Rule 23(c)(2): Minnesota v. United States Steel Corp., 44 F.R.D. 559, 577 (D. Minn. 1968); Iowa v. Union Asphalt \& Roadoils, Inc., 281 F. Supp. 391, 403 (S.D. Iowa 1968). Those citing Rule 23(d) were Brennan v. Midwestern United Life Ins. Co., 450 F.2d 999, 1004 ( 7 th Cir. 1971); Iowa v. Union Asphalt \& Roadoils, Inc., supra at 403; and Harris v. Jones, 41 F.R.D. 70, 74-75 n.9 (D. Utah 1966). The court in Philadelphia Electric Co. v. Anaconda Amer. Brass Co., 43 F.R.D. 452, 459 (E.D. Pa. 1968), seemed to rely on Rule 23 generally. 
contemplated by the Advisory Committee. ${ }^{21}$ One court, however, has argued that subdivision (c)(2) does not prohibit the imposition of affirmative requirements on absent class members because the rule does not limit the matters that can be included within the notice.22 This argument ignores the fact that the requests for information from absent class members are not commonly understood as notice. They are more in the nature of discovery.

Under Rule 23(d), only subdivisions (d)(2) and (d)(3) could possibly apply to requests for information from absent class members, but even these fall short. Subdivision (d)(2) merely enables the court to keep class members informed as it deems necessary: ${ }^{23}$ The court may invite absent class members to comment upon the adequacy of representation or to intervene and present claims. ${ }^{24}$ Nothing in the provision, however, authorizes orders requiring production of discovery-like information from class members or subsequent orders dismissing claimants. ${ }^{25}$ Indeed, by referring to the "opportunity" to intervene, the rule suggests that any action would be voluntary, not mandatory.

Justification of pre-trial discovery of absent class members would require that class members who respond be considered intervenors. ${ }^{26}$ This, however, conceptually transforms the class suit into a permissive joinder. ${ }^{27}$ This view would undermine the function of class

21. FE. R. Civ. P. 23(c)(2), Advisory Committee's Note, 39 F.R.D. at 104-05. See 7A WRIGHT \& MILLER, supra note 2, \$ 1787, at 159.

29. Iowa v. Union Asphalt \& Roadoils, Inc., 281 F. Supp. 396, 403 (S.D. Iowa 1968).

23. Kaplan, Continuing Work of the Civil Committee: 1966 Amendments of the Federal Rules of Civil Procedure, 81 HARv. L. Rev. 356, 393-94 (1967). Professor Kaplan, reporter and later member of the Advisory Committec, explained that $23(d)$ consists of "a number of discretionary steps available to the court for better management of class actions generally. Among them are orders requiring, for the protection of the members of the class or otherwise for the fair conduct of the action, that notice be given to some or all members of the class informing them of any event in the action, or of their opportunity to speak their picce on the adequacy of the representation, or to intervene in the action. Here the Committee was responding to Professor Chafee's remark, echoed by others, that class members "ought to be informed as well as represented." "Id.

24. See note 20 supra.

25. Subdivision (d)(2) of Rulc 23 enables the court to give notice "for the protection of the members of the class or otherwise for the fair conduct of the action." Protection of class members scems the primary consideration since all of the types of notice authorized therein would be helpful to class members; it is difficult to see how this provision could be used to the detriment of class members' interests.

26. The only language in this provision which refers to actions of the sort typically required by courts under it, e.g., proof of claim, see note 6 supra, is the following: " $[\mathrm{T}]$ he court may make appropriate orders ... requiring . . . that notice be given .. of the opportunity of members ... to intervene and present claims or defenses ..." FED. R. Civ. P. 23(d)(2) (emphasis added).

27. See FED. R. Civ. P. 20(a), wherein any number of persons may join in one action as plaintiffs (or as defendants) if they share a right to relief (or a right to relief is asserted against them) arising out of the same transaction or occurrence and involving a common question of law or fact. The old version of Rule 23 , which re- 
actions. Instead, the Advisory Committee apparently assumed that, under this provision, class members would be notified to present claims after the basic class liability decision had been rendered.".s Thus, under 23(d)(2) absent class members may be treated as intervenors in the latter part of a trial when they present their claims, but they cannot be characterized as intervenors prior to trial.

Subdivision (d)(3), the only other section of the rule which might be relevant, merely enables the court to impose conditions "on representative parties or on intervenors." Absent class members, however, are neither representative parties nor intervenors. To be representative parties they must have been qualified by a court determination that their claims or defenses are typical of those of members of the class and that they will fairly and adequately protect the class interest; ${ }^{29}$ to be intervenors they must have moved to intervene and must have been permitted to do so by the court. ${ }^{30}$ The intent of the Advisory Committee was simply to allow the court to condition the maintenance of the class action on the strengthening of the representation, perhaps by the intervention of additional parties, or to impose conditions on intervenors to assure "proper and efficient conduct of the action." 31 Thus, this provision furnishes no basis for imposing conditions on absent class members.

\section{Competing Considerations}

The lack of an explicit authorization on the face of the rules for gathering detailed information from class members does not necessarily end the inquiry. Serious problems which the rules do not directly address may justify judicial experimentation through the liberal interpretation of those rules. ${ }^{32}$ At the same time, however, experimentation can only be justified insofar as it is geared toward solution of problems which presently exist with due regard for the com-

quired some affirmative action of potential class members prior to trial in "spurious" suits, was considered a permissive joinder device. See 3 MoORE's Federal Practice 93.10 , at 2601 (2d ed. 1969). The courts' use of the new rule to require affirmative action is functionally equivalent.

28. FED. R. Crv. P. 23(d)(2), Advisory Committee's Note, 39 F.R.D. 69, 106. The Committee explained: "For example, in 'limited fund" cases, members of the class have been notified to present individual claims after the basic class decision" of liability to the class. Id. at 106.

29. FED. R. Giv. P. 23(a)(3), (a)(4).

30. FED. R. CIV. P. 24.

31. FED. R. Civ. P. 23, Advisory Commitlee's Note, 39 F.R.D. 69, 107.

32. Such experimentation in the absence of express authorization by the rules is not uncommon; cf. I Moore's Federal Practice: Maxual for Complex litigation (2d ed. 1969). 
peting considerations behind the rules. The considerations which must be examined and ultimately balanced in this context are the protection of class members, the courts' manageability demands, and justice to the defendants.

\section{A. Protection of Class Members}

A primary concern of the courts should be the protection of the class members themselves. Because of the impracticality of bringing all the members of a large class before the court in one suit, Rule 23 and its 1966 revision permits a few representative class members to bring the action on behalf of the entire class. ${ }^{33}$ The resulting judgment in the suit becomes binding on all class members who failed explicitly to request exclusion from the class. ${ }^{34}$ Previously class members had to "opt in" to be included, but in 1966 the Advisory Committee changed the rule to require class members to "opt out."3s Specifically, the Committee sought not only to prevent problems of multiple litigation but also to preserve the claims of individuals who are unlikely to take affirmative action, perhaps due to "timidity, ignorance or unfamiliarity with business or legal matters." ${ }^{36}$ Believing that one goal of the class action was to protect the individual with a small claim and fearful that small claimants would fail to respond to class action notices, the Committee determined that a nonresponse would mean inclusion rather than exclusion. ${ }^{37}$

The Advisory Committee's notion of the class action's "historic mission of taking care of the smaller guy" 38 reflects actual usage. The class action device provides a forum for small claimants because it is especially appropriate for those who "are in a poor position to seek legal redress, either because they do not know enough or because such redress is disproportionately expensive." 39 Moreover, in

33. FE. R. Civ. P. 23, Advisory Commillee's Note, 39 F.R.D. at 104.

34. FEv. R. Civ. P. 23(c)(2)(B).

35. See 3B Moore's Federal Practice f 23.02-1, at 121, 124; ff 23.10[1], at 2601-03 (2d ed. 1969).

36. Kaplan, supra note 23 , at 998.

37. See Frankel, Amended Rule 23 from a Judge's Point of Vieu', 32 ANTrrousr L.J. 295, 299 (1966) [hereinafter cited as Frankel, Amended Rule 23]. Professor Kaplan explained the Committee's reasoning as follows:

[R] equiring the individuals affirmatively to request inclusion in the lawsuit would result in freczing out the claims of people-especially small claims held by small people-who for one reason or another ... Will simply not take the affirmative step .... [Thus] it seems fair for the silent to be considered as part of the class. Kaplan, supra note 23 , at $397-98$.

38. Frankel, Amended Rule 23, supra note 3i, at 299 (quoting a conversation with Kaplan).

39. Kalven \& Rosenfield, The Contemporary Function of the Class Suit, $8 \mathrm{U}$. CHI. L. REv. 684, 686 (1941). 
a society where a single harmful act may cause damage to a large number of people, the class action can be an important means of protecting scattered rights. ${ }^{40}$ Class suits also have a deterrent effect. They encourage large businesses to be straightforward in their dealings with individuals over small claims. ${ }^{41}$ And if they fail to deter, they may still deprive large concerns of unjust enrichment in circumstances where the individual claims are too small to justify individual lawsuits.

Forcing class members, in effect, to "opt in" by furnishing information may undermine the policy of the class action rule in two ways. First, courts permitting discovery make the unresponsive small claimant vulnerable to defendants who, in an effort to minimize their liability, engage in extensive discovery of class members for the sole purpose of reducing class size and thus the potential amount of recovery. Second, the practice of forcing members to "opt in" has imposed a double duty on class members. They must take action not only to be excluded, but also to be included in the judgment. This double duty requirement means that class members by their inaction may be both bound by res judicata with respect to future actions and barred from recovery in the present. Under the original rule class members had only to take one action, namely to request inclusion. Those members failing to respond were not bound by the judgment. The revised rule requires class members to take action only if they want to be excluded from the action and judgment. The double duty practice thus imposes a heavier burden than either the old or present Rule 23, for it demands that class members meet the requirements of both. ${ }^{42}$

By contrast, the defendant has the advantages of both the old and new Rule 23. As under the old rule, the defendant, if found liable by a court which had permitted him discovery, need only satisfy the

40. See Dolgow v. Anderson, 43 F.R.D. 472, 482 (E.D.N.Y. 1968); Frankel, Amended Rule 23, supra note 37 . Kaplan, supra note 23 , at 398 , suggests that a class action is similar to an administrative proceeding wherein scattered interests are represented by the government. See generally Hazard, Class Actions: The Effect of the Class Action Device Upon the Substantive Law, 58 F.R.D. 299.

41. See Dolgow v. Anderson, 43 F.R.D. 472,487 (E.D.N.Y. 1968). See also id. at 473 (on the usefulness of class actions to deter securities fraud) and Weinstein, Class Aclions: Some Reflections on the "Abusiveness" of Class Actions, 58 F.R.D. 299, 304-05.

42. Furthermore, this double duty may confuse the class member. At the outset of the action the class member is led to understand that he will be included unless he withdraws, but he later learns that he must make an active effort to prevent his claim from being dismissed. Professor Wright stggests that courts should weigh the confusion problem in deciding whether to require proof-of-claim statements. $7 \mathrm{~A}$ WricHT \& Miller, supra note $2, \S 1787$, at 159 . The Brennan court found the confusion argument relatively persuasive, but required class members to respond nonetheless. Brennan v. Midwestern United Life Ins. Co., 450 F.2d 999, 1005 (7th Cir. 1971). 
claims of those who took action to insure inclusion. At the same time the defendant is protected by the rule revision against one-way intervention ${ }^{43}$ and multiple litigation, ${ }^{44}$ since the judgment binds all who do not exclude themselves.

\section{B. The Courts' Manageability Demands}

Courts sometimes advance the argument that requiring information of absent class members will render the suit more manageable. For example, some courts have required class members to file statements of intent to prove damages prior to trial, because it would serve "expediency" and permit "an early determination of which parties intend to offer proof of damages." 4 s Other courts have preferred to receive proofs of claim prior to adjudication of liability because it would reveal the "scope of the litigation" and provide a "meaningful" verdict." It would thus appear that these courts, anxious about managing class suits, feel more comfortable with the original version of Rule 23, wherein class members had to "opt in," and believe that procedure can be preserved despite the rule revision. ${ }^{47}$ A return to the old rule, however, will not aid manageability, since much of the information sought is not needed at so early a stage. Early receipt of statements of intent to prove damages, proofs of claim, information about circumstances surrounding the claim, and reliance of the claimant does not simplify a class action,

43. Under old Rule 23 class members were sometimes allowed to intervene after the court determined defendant's liability to the class. See Union Carbide \& Carbon Corp. v. Nisley, 300 F.2d 561, 588-89 (10th Cir. 1961). This practice of "one-way intervention" secmed unfair in that class members could await the determination of liability before joining the action, thus incurring no risk. See also Kaplan, supra note 23, at 385-86. Under the revised rule class members who do not "opt out" are bound by res judicata to whatever judgment is rendered, thus eliminating any "sideline sitting."

44. "Under the original rule only those who "opted in" were included in the judgment, making multiple actions possible. Thus, the defendant might be forced to defend a number of small lawstits at high cost. The new rule is particularly advantageous for the defendant "in that it attempts to conclude the class when the decision is unfavorable to it." Kaplan, supra note 23 , at 397.

45. Iowa v. Union Asphalt \& Roadoils, Inc., 281 F. Supp. 391, 403, 404 (S.D. Iowa 1968).

46. Philadelphia Electric Co. v. Anaconda Amer. Brass Co., 43 F.R.D. 452, 459, 462 (E.D. Pa. 1968); Harris $v$ Jones, 41 F.R.D. 70, 75 n.10 (D. Utah 1966). The Harris court asserted that the class action "may prove both manageable and beneficial if, and only if, the members of the class can be brought in some way before the court prior to trial." Id.

47. For example, the court in Philadelphia Electric Co. v. Anaconda Amer. Brass Co., 43 F.R.D. 452 (E.D. Pa. 1968), observed that the approach of the old rule was similar to that of permissive joinder and asserted that the advantages of the permissive joinder approach could be "retained under the present rule," $i d$. at 459 , impliedly by requiring absent class members to take some affirmative action prior to trial. "Under the new rule, ... if [passive members] have no intention of proving their individual damages, it is to everyone's advantage to know it early." Id. 
for it is common practice to administer class actions in two stages, with the issue of liability heard first and the question of damages postponed until later. ${ }^{48}$ The Advisory Committee explicitly authorized these so-called split trials under the rule and indeed advocated their use. ${ }^{49}$ Thus, the need, if any, for such information at the outset is substantially reduced.

In some situations, however, courts may require information of class members in order to determine or reappraise the class action designation. ${ }^{50}$ Before a class action may proceed under $(b)(3)$, the court must discern whether common questions predominate over questions affecting individual members. For example, in a securities fraud case the court must make a determination that the fraud involved similar misrepresentations and reliance.51 Yet in many cases this information will not be necessary; a number of courts have refused to apply a strict requirement of similar misrepresentations and reliance to such class actions. ${ }^{52}$ Moreover, notwithstanding that such

48. Courts using or approving such split trials include: Green v. Wolf Corp., 406 F.2d 291, 301 (2d Cir. 1968); Eisen v. Carlisle \& Jacquelin, 391 F.2d 555, 556 (2d Cir. 1968): Fischer v. Wolfinbarger, 55 F.R.D. 129, 132 (W.D. Ky. 1971); Berland v. Mack, 48 F.R.D. 121, 126 (S.D.N.Y. 1969); Mersay v. First Republic Corp., 43 F.R.D. 465, 471 (S.D.N.Y. 1968); Dolgow v. Anderson, 43 F.R.D. 472,490 (E.D.N.Y. 1968). See also Frankel, Some Preliminary Observations Concerning Civil Rule 23, 43 F.R.D. 39, 47 \& $n .11$ (1968) [hereinafter cited as Frankel, Observations]. Judge Frankel advocates the use of split trials and suggests that many judges, including the district judge in Harris, could have used a split trial instead of attempting to bring all class members before the court. Judge Frankel noted that "[i]f the common questions have been aptly defined, there should be no need at an earlier stage to have all the individual class members before the court for discovery or any other purpose." Id. at 47 .

49. FED. R. CIv. P. 23(c)(4), Advisory Committee's Note, 39 F.R.D. 69, 106.

50. See 3B Moore's Federal Practice fo 23.71, at $1411-12$ (2d cd. 1971). Any appraisal of the class status raises a different question of what a court can infer from the failure of class members to respond. A court might conceivably conclude from a minimal response that the class was not so numerous that a class action was justified. See FED. R. Civ. P. 23(a)(1), (c)(1). Yet a lack of response does not mean that there is no class nor does the language of the revised rule support such an inference. Some courts have held that a lack of apparent class interest was not a compelling reason for refusing to maintain a class action and that the rule does not permit such "subjective inference." Korn v. Franchard, 456 F.2d 1206, 1209-10 (2d Cir. 1972); Mersay v. First Republic Corp., 43 F.R.D. 465, 470-71 (S.D.N.Y. 1968).

51. FEd. R. Civ. P. 23(b)(3), Advisory Committee's Note, 39 F.R.D. 69, 103. See also Harris v. Jones, 41 F.R.D. 70,73 (D. Utah 1966). The court in Harris cited varying forms of alleged misrepresentations and reliance by class members as a reason for requiring detailed information from absent class members. Yet the Harris case scems an obvious choice for a class action since, in one subclass at least, the misrepresentations were promulgated by way of commercial advertising broadcasts-by nature similar, if not the same, misrepresentations. Id. at 72 .

52. Courts have developed a lenient attitude toward variations in reliance, particularly in 10b-5 securities fraud cases. See Mersay v. First Republic Corp., 43 F.R.D. 465, 471 (S.D.N.Y. 1968), wherein the court noted that variations in proof of reliance are rarely so substantial as to defeat the class action, and Rule $10 \mathrm{~b}-5$ cases always involve variation in the kind and degree of reliance of each individual investor. See also Fischer v. Kletz, 4I F.R.D. 377, 382 (S.D.N.Y. 1966). Indeed in Fischer v. Wolfinbarger, 55 F.R.D. 129, 132 (W.D. Ky. 1971), the court held that it was not necessary for the plaintiffs to establish "reliance" in order to recover under Rule $10 \mathrm{~b}-5$ and the Se- 
information is in some sense "necessary," the small claimant is often incapable of supplying it because he lacks the "sophistication and knowledge" to provide a meaningful response. ${ }^{53}$ Finally, it should be noted that failure of class members to respond does not lock a court into a class action, since it may reconsider the class action designation at any time prior to judgment. ${ }^{54}$

If information from class members is indeed necessary for manageability and fairness, courts may frequently be able to obtain it in other ways. Specifically, courts could require the class representatives to furnish information about, for instance, their own reliance on alleged misrepresentations of the defendant, the nature of the class, and anything else needed to rule on the appropriateness of a class action. ${ }^{55}$ Another court urged the use of less burdensome means of discovery whenever available, suggesting sampling techniques whereby questions are directed to a limited number of class members selected randomly or on the basis of comprehensiveness of records. ${ }^{.63}$

curities Act of 1933, 15 U.S.C. $\$ 77 a$ (1970), and the Securities Exchange Act of 1934, 15 U.S.C. $\$ 78(1970)$.

Other courts have expanded the definition of "similar misrepresentations." For cxample, in Fischer v. Kletz, 41 F.R.D. 377 (S.D.N.Y. 1966), the court ruled that data in a scries of corporate financial statements, though varying from statement to statcment, were interrelated and cumulative and thus raised common questions suitable for class action determination. In Kronenberg v. Hotel Governor Clinton, Inc., 281 F. Supp. 629, 696 (S.D.N.Y. 1967), the court suggests that the new Rule 23 provides the flexibility to maintain a class action with different kinds of representations, because the court can always dismiss the suit as a class action at a later stage and allow it to procecd on behalf of the named plaintiffs alone.

53. Sec Korn v. Franchard, 456 F.2d 1206, 1210-11 (2d Gir. 1972). The court noted that "the returned proof-forms reveal a group which is lacking in the kind of sophistication and knowledge which would assure a meaningful response so many years later as to the specifics of misrepresentations or omissions, even assuming that the respondents understood the questions." The same problems might develop in other class actions where the class is comprised of laymen and the issues are complex. The court noted that the proof-of-clain procedure has usually been used in antitrust claims "made by government entities where detailed records were kept and objective questions on proof of damages asked," id. at 1211 n.12, citing Note, The Impact of Class Actions on Rule 10b-5, 38 U. CH. L. Rev. 337, 35I n.80 (1971). When the class members are not small claimants but large businesses or government agencies, there may be less justification for preserving claims until recovery is assured.

54. FED. R. Civ. P. 23(c)(1). But at least one judge points out that the courts might not feel as comfortable about subsequently dismissing the suit as a class action if a statute of limitations had run. Frankel, Observations, supra note 48 , at 42 .

55. For cxample, the representative parties in one antitrust class action furnished the court with a list of prospective class members, information which would provide an indication of class size, possible subclasses, and the extent of potential liability. Iowa v. Union Asphalt \& Roadoils, Inc, 281 F. Supp. 391, 403 (S.D. Iowa 1968).

56. Unreported opinion of Illinois v. Harper \& Row Publishers, Inc., No. 67-C-1899 (N.D. Ill., Feb. 13, 1970), set out in Petition for Writ of Certiorari, App. III, Herriman v. Midwestern United Life Ins. Co., cert. denied, 405 U.S. 921 (1972) (Sup. Ct. docket no. $71-778$ ).

See also In re Antibiotic Antitrust Actions, 333 F. Supp. 278, 288 (S.D.N.Y. 1971), whercin the court refused to require proofs of claim before judgment in the consumer 
Sometimes, however, information which is obtainable only by a survey of the entire class, for example, statistical data or bulk information on class size or characteristics, may contribute to the manageability of a class action by enabling the court to determine the appropriateness of subclasses or the adequacy of class representation. Conceivably, information on class size could lead to a settlement, which, by obviating a trial, would more expeditiously dispose of large class suits. In any event, class members may supply the information as readily without the threat of bar to recovery. ${ }^{57}$ And even if recovery is barred in a present suit, there is no compelling reason to bar the bringing of a future action.58

\section{G. Justice for Defendants}

The final consideration in the concern for manageability and fairness is justice for the defendant. A defendant may claim that the information from absent class members is necessary for his defense. ${ }^{59}$ In most cases, however, such information is unnecessary to determine the fact of liability. For example, interrogatories seeking detailed information on individual claims or damages prior to trial would not be necessary if the liability issue were being tried in a proceeding separate from the damage issue. ${ }^{60}$ If the information is important for the defense, it might be obtained in other ways-from representative parties, for instance. Theoretically, discovery information from representative parties should be typical of the entire class. Even if that discovery proved insufficient, courts could ensure

class but offered to "aid the parties in 'sampling' or conducting a more intensive study of the claims within a representative state or subdivision ..."

Such sampling techniques might be particularly helpful for a court's determination of whether a proposed settlement in fact protects the interests of the class as a whole. See p. 622 infra.

57. The number of class members in Brennan who ultimately answered the discovery interrogatories totaled 421 out of a class of 535 members. While the threat of penalty may have contributed to this relatively large response, it may also be attributable to the fact that counsel for the named plaintiff sent three requests to each previously unresponding class member over a six-month period. Brennan v. Midwestern United Life Ins. Co., 450 F.2d 999, 1002-03 (7th Cir. 1971), and Briefs for Appellants, App. at 123 , id.

58. It is true that failure to bar permanently the claims of nonresponding class members leaves open the possibility of multiple litigation. It seems unlikely, however, that class members who fail to participate in a pending class suit will bring their own actions later.

59. See Brennan v. Midwestern United Life Ins. Co., 450 F.2d 999, 1005 (7th Cir. 1971); cf. Iowa v. Union Asphalt \&. Roadoils Co., Inc., 281 F. Supp. 391, 404 (S.D. Iowa 1968), wherein the court cited "fairness to the defendants" as a reason for requiring affirmative action from class members. See p. 603 supra.

In a diversity action, for instance, the defendant may claim that not all absent class members can meet the jurisdictional amount requirement of 18 U.S.C. $\$ 1332$ (1970). See Zahn v. International Paper Co., 42 U.S.L.W. 4087 (U.S. Dec. 17, 1973); p. 62I infra.

60. See, e.g., Gardner v. Awards Marketing Corp., 55 F.R.D. 461, $463-64$ (D. Utah 1972). 
fairness by enlarging the number of representative parties. Class members of a particular type could be required to intervene as a condition of the action's continuing as a class suit. ${ }^{61}$ Indeed provisions (d)(3) and (c)(I) ${ }^{62}$ of the class action rule specifically authorize this method of strengthening the representation in a class action.

If, on the other hand, the information is of a type only available from absent class members, justice may be served without resort to the extreme sanction of dismissal with prejudice for failure to respond. If the purpose of a sanction is to induce compliance, ${ }^{63}$ a court should use the mildest sanction that will produce the desired result. If the Advisory Committee's expectation that absent class members are likely to remain passive is accurate, ${ }^{04}$ the threat of sanction may not affect the rate of response at all. It was just this assumption of the court in the Antibiotic Antitrust Cases which led it to exempt individual class members from submission of the claim requirements imposed upon government entities within the class. Individual class members were unlikely to respond, said the court, until they were assured of recovery since their claims were so small. ${ }^{65}$ In practice, then, the layman's response to a formal request is probably unaffected by threatened sanction.

\section{Solutions}

In all likelihood the draftsmen of Rule 23 did not fully anticipate such problems as discovery of absent class members and immense class size. Consequently, courts have had to implement innovative procedures to make class actions more just and manageable. Such adaptation should not be discouraged. With the increas-

61. For example, the court could require the intervention of several representative parties from each of several classes of purchasers, e.g., retailers, wholesalers, and consumers. Or the court might require intervention of representative parties reflecting the varying circumstances and types of misrepresentation and reliance.

62. FED. R. CIv. P. 23(c)(1), (d)(3), Advisory Committee's Note, 39 F.R.D. 69, 104, 107. The Committee stated:

An order embodying a determination can be conditional; the court may rule, for cxample, that a class action may be maintained only if the representation is improved through intervention of additional parties of a stated type.

Id. at 104. The Committee also observed that, "Subdivision (d)(3) reflects the possibility of conditioning the maintenance of a class action ... on the strengthening of the representation ...." Id. at 107.

63. It might be argued that the purpose of a sanction is not to secure compliance, but to punish. The punishment of dismissal with prejudice, however, is out of all proportion to the harm caused by nonresponse.

64. See Kaplan, supra note 23, at 397-98; cf. Frankel, Amended Rule 23, supra note 37 , at 299.

65. 333 F. Supp. 267, 271 (S.D.N.Y. 1971); 333 F. Supp. 278, 280, 282, 288 (S.D.N.Y. 1971). 
ing complexity of class actions courts need the flexibility to experiment and develop solutions gradually before a particular procedure is solidified in a rule. The recommended procedures for complex and multidistrict litigation evolved from a similar pattern of trial and error. ${ }^{66}$ Problems under Rule 23 can also be eliminated through evolving management techniques. Any movement to revise the rule again is premature; it is too early to pass judgment. ${ }^{67}$ However, courts must not disregard the purpose and language of the revised rule in their efforts to resolve the problems of justice and management.

An ideal solution would reconcile needs for discovery with the class action rule, balancing the competing considerations. The defendant must be allowed to discover information essential to his defense, and yet the class must not be harassed by defendants using discovery solely to diminish the class and their potential liability. ${ }^{\circ}$ Courts must strive for class action manageability and prevent problems of multiple litigation without contravening the language and intent of Rule 23. At present, there seems to be no single solution; instead, a number of procedures should be applied selectively as the circumstances of a particular case require.

\section{A. No Discovery of Absent Class Members}

In most cases the court should deny discovery of absent class members and refrain from questioning them, ${ }^{69}$ using alternative measures to ensure manageability and fairness. Specifically, better use of split trials and representative parties would obviate the need for discovery of absent class members in many instances. Whether sought by the court or the opposing party, information from absent class members regarding claims, reliance on alleged misrepresentations, circumstances surrounding purchase, proofs of claim, or statements of in-

66. See generally 1 Moore's Federal Practice: Manual for Complex Litigation (2d ed. 1969).

67. But see Report and Recomimendations of the SPEcial Committer on Rule 23 of the Federal Rules of Civil Procedure of the American College of Trial Litwyers, Revised Drift OF RULE 23 (1973).

68. One federal judge stiggests that the courts have an "additional responsibility to protect absent class members in the complex class actions of today." Weinstein, supra note 41 , at 300 . Professor Wright argues that discovery and proof-of-claim procedures should be limited in order to prevent defendants from using discovery to induce class members to exclude themselves. $7 \mathrm{~A}$ WRIGHT \& MILLER, supra note 2, $\$ 1792$, at $196 \mathrm{n} .96$.

69. Class members would still be subject to discovery under FED. R. Civ. P. 30 (Depositions Upon Oral Examination) and 31 (Depositions Upon Written Questions), which permit discovery "of any person." However, this procedure is more expensive for defendants, and unlikely to be used except in special situations where it is clear that a particular class member has important information. 
tent to prove claims is not necessary prior to a determination of liability, but becomes pertinent only in the second stage of a split trial. Information about the nature or composition of the class, information regarding evidence to be presented by plaintiffs, and clarification of allegations can be supplied by the representative parties. For example, one court allowed unusually generous discovery of representative parties to compensate for prohibiting discovery of absent class members. ${ }^{70}$ Representative parties might also assist a court in determining whether a class action is appropriate or how best to conduct the action, both decisions that must be made early. ${ }^{71}$ Furthermore, courts have the authority to order the intervention of additional representative parties to expand sources of information. ${ }^{22}$ For example, the court might require intervention of representative parties who reflect different circumstances, types of misrepresentation, or reliance of various subclasses.

This alternative satisfies a number of considerations. It manifests a strict adherence to the language and intent of Rule 23; it eliminates the potential misuse of the discovery process to decimate the class; it mitigates problems of multiple litigation, for all unresponsive class members would be bound by the judgment; and by restricting discovery to representative parties prior to a finding of liability, it serves the goal of manageability more adequately than does subjecting numerous class members to interrogatories or proof-of-claim requirements. Although some courts seem to feel an action is manageable only if all class members are assembled and brought before the court at the outset, ${ }^{73}$ it is apparent that such measures, rather than enhancing manageability, may have the opposite effect. The costs of securing information from representative parties or securing it from class members after liability has been established would, in

70. Wainwright v. Kraftco Corp., 54 F.R.D. 532, 535 (N.D. Ga. 1972). This court allowed interrogatories only to the party plaintiffs, the Atlanta and Rome Boards of Fducation, but because plaintiffs intended to prove a statewide conspiracy with evidence relating to Atlanta and Gainesville activities, the court permitted defendants to discover "work-product" from the Atlanta Board under Rule 26(b)(3), namely "all information that it [the Board] has collected with respect to Gainesville and any other school boards, including a list of the names of persons to whom the Atlanta Board has spoken so that defendant may take their depositions." The court also pointed out that defendants were free to use "other discovery techniques available as to non-parties." Id. at 535.

71. Representative parties have an interest in providing information on the appropriateness of a class action because a court decision against allowing a class action could make continuation of the suit by them as individuals less attractive.

72. See note 62 supra.

73. See Harris v. Jones, 41 F.R.D. 70, 75 n.10 (D. Utah 1966). See also Philadelphia Electric Co. v. Anaconda Amer. Brass Co., 43 F.R.D. 452, 459 (E.D. Pa. 1968); lowa v. Union Asphalt \& Roadoils, Inc., 281 F. Supp. 391, 403-04 (S.D. Iowa 1968). 
most cases, be less than multiple communications with all class members. ${ }^{74}$ This alternative would not be adequate, however, if the representative parties cannot provide information needed by the defendant to defend on the merits or by the court to make a determination of representativeness; in these situations one of the alternative solutions might be more suitable.

\section{B. Discovery With No Penalty}

A second alternative would allow discovery of absent class members, without a penalty for nonresponse. ${ }^{75}$ A defendant could seek unlimited discovery of absent class members and the court would be unrestricted in its efforts to survey or define the class and the issues. This procedure would comply with the letter and spirit of the rule, for class members would be included unless they chose to "opt out" without an additional requirement of affirmative action to assure recovery. For the same reason this alternative would preclude multiple litigation and abuse of the discovery process to diminish the class.

Discovery without sanction could also be used as a preliminary step to determine if subclasses are necessary or if further discovery would serve any useful purpose. In Brennan v. Midwestern United Life Insurance Company, for example, the use of discovery without a sanction might have revealed that the asserted defenses were not sustainable. ${ }^{70}$

74. A requirement that all claims be presented prior to trial might climinate the need for subsequent notice and discovery if further proof of damages or reliance were unnecessary, but it would result in wasted judicial resources and unnecessary costs if liability to the class were not established in the first procceding. Court costs in general might be reduced, however, if early information from absent class members revealed that a class action was inappropriate or if it induced settlement, because the expense of conducting a trial would be obviated.

75. The court in Korn v. Franchard urged this approach, saying, "Unless and until liability to the class is established or seems reasonably certain ..., members should not be barred for failure to track down [the requested] information, even though such a requirement might later be a reasonable condition to their participation in any recovery, assuming liability is established." 50 F.R.D. 57, 60 (S.D.N.Y. 1970). This approach has also been used in cases where the court itself sought information from class members. In Arey v. Providence Hospital, 55 F.R.D. 62 (D.D.C. 1972), a class action under Title VII, 42 U.S.C. $\$ \$ 2000 \mathrm{e}$ et seq. (1970), the court sought information regarding discriminatory employment practices in order to make effective rulings on the boundaries of the class, the need for subclasses, and the individual rights of class members, and to aid a possible reevaluation of the suitability of class status in general. The court refused to bar from recovery those members who failed to supply the 1equested information. Id. at $71-72$. See also Knight v. Board of Educ,, 48 F.R.D. 108 (E.D.N.Y. 1969), where the court sent questionnaires to class members under the notice provisions of $23(\mathrm{~d})(2)$, but used or threatened no penalty.

76. Brennan v. Midwestern United Life Ins. Co., 450 F.2d 999 (7th Gir. 1971). Midwestern sought discovery in order to establish (1) that it had not received information that could reasonably be expected to put it on notice of certain fraudulent activities and cause it to report them to the Securities Commissioner, and (2) that plaintiffs' 


\section{Discovery With the Sanction of Exclusion}

Another approach would permit discovery backed by the sanction of excluding silent members from the class without prejudice to their individual claims. ${ }^{77}$ Unresponsive class members would be denied the benefit of recovery through the class action, but would be permitted to press their own causes of action at a later date. Unlike one-way intervention, ${ }^{78}$ the class member would not be permitted to join the class suit after liability was established, but would have to bring a separate action at his own risk and expense..$^{70}$

This procedure should be implemented in connection with a standard for discovery of absent class members which is higher than that for the representative plaintiffs. This would insure that the defendant is acting in good faith and that unnecessary multiple litigation is avoided. Courts could require proof that the desired information was necessary for the defense and unavailable from representative parties or by any other realistic means, ${ }^{\text {s0 }}$ including defendant's own records. ${ }^{81}$ Under this standard, which is similar to that required to obtain work-product discovery of another attorney, ${ }^{82}$ a court would have to weigh the cost of alternative means of obtaining the information to determine if such means were "realistic."

The proposed standard shares the recognition in Brennan $v$. Midwestern United Life Insurance Company ${ }^{83}$ that discovery of absent class members should not be allowed "as a matter of course," but it requires satisfaction of a higher burden than the Brennan "necessary

injuries were not caused by its failure to report to the Securities Commissioner because the purchasers themselves had reported more information than the company knew of. Brief for Appellees at 4-5, id.

77. Cf. Quinault Allottee Ass'n v. United States, 453 F.2d 1272, 1277 (Ct. Cl. 1972). Note, however, that the Court of Claims was not bound to follow Rule 23. See note 2 supra.

78. See note 43 supra.

79. Once defendant's liability to the class is established, individuals excluded from the class might be able to recover, under the doctrine of collateral estoppel. However, such a practice increasingly resembles one-way intervention and could result in the sideline-sitting which the 1966 revision to Rule 23 sought to eliminate. See note 43 supra.

80. Cf. Gardner v. Awards Marketing Corp., 55 F.R.D. 460, 463 (D. Utah 1972), where the court suggested that interrogatories to the class be allowed only "upon a strong showing of necessity or at least of likely material aid in the resolution of common issues."

81. See Weinstein, supra note 41 , at 303. Judge Weinstein noted that although class members typically do not have adequate records regarding damages, often the records of the defendant, "particularly in securities cases," will contain the information. The same would seem to apply to antitrust cases.

82. See Fed. R. Civ. P. 26(b)(3). See also Hickman v. Taylor, 329 U.S. 495 (1947), wherein the Supreme Court suggested that discovery of an attorney's work-product would be allowed only upon a showing of necessity or a showing "that denial of production would cause hardship or injustice." Id. at 509.

83. 450 F.2d 999 (7th Cir. 1971). 
or helpful" test and imposes a milder sanction than dismissal with prejudice. ${ }^{84}$ The court in Brennan, a Rule $10 \mathrm{~b}-5$ securities fraud action, reasoned that discovery of absent class members was acceptable when "necessary or helpful" to the proper presentation and adjudication of the suit and that "justice to all parties" requires it as long as it is not being used to reduce the size of the class or to take undue advantage of class members. ${ }^{85}$ However, the problems that arise from such a test are manifold. The "necessary or helpful" language is broad and prone to subjective interpretation; almost all discovery efforts could fall within one of the two categories, which seem to exclude only that discovery which may be termed "useless." The second part of the Brennan test contributes even less to the search for a more objective standard. Discovery to ensure "justice to all parties" offers no concrete guidelines; it is an expression of the conclusion that discovery should take place. The third test, that discoivery not be allowed to reduce or take advantage of the class, is an imperative condition but unfortunately difficult to enforce. The Brennan court, finding nothing in the record to suggest an ulterior motive, was satisfied. Discovery efforts, however, can have a dual purpose; some interrogatories appearing reasonable under the mild Brennan test could in fact be used to harass class members and reduce their numbers.

The proposed approach satisfies a number of important considerations. A defendant complying with the stricter standard, having demonstrated a clearly legitimate purpose for discovery, cannot be accused of abusing the discovery process to the detriment of absent class members. ${ }^{86}$ In addition, the exclusion penalty would not irrevocably harm passive class members, for they would not be barred from recovery in a separate suit. This procedure should satisfy those who believe that some threat is necessary to secure compliance. And although it does not comply literally with Rule 23 , this procedure would come closer to implementing its intent to protect the small claimant than does the current practice in some suits of dismissing the nonresponding class member with prejudice.

84. Id. at 1005. Professor Wright suggests that a milder sanction would have been appropriate in Brennan. 7A WRIGHT \& MILlER, supra note 2, $\$ 1792$, at $196 \mathrm{n.98}$.

85. $450 \mathrm{~F}, 2 \mathrm{~d}$ at 1005.

86. The court, which could have no similar interest in abusing the discovery process, would not judge the necessity of obtaining information from absent class members to serve its manageability needs by this higher standard. The court should nevertheless consider the effect of such information requirements on the class. For example, if court-initiated interrogatories would require legal or technical assistance to answer, the court should carefully consider the need for the information in view of the possibility that many class members would fail to respond. 
Nor would this approach engender serious problems of multiple litigation. The higher standard for discovery would ensure that class members were not subject to exclusion as a matter of course. Moreover, the class member who did not respond to informational requests is unlikely to take the initiative to bring his own action after exclusion.

The higher discovery standard would have the disadvantage of increased court costs, however. The administration of a court-imposed test could involve the court in controversies and determinations requiring close supervision of the discovery process, contrary to the recent trend under the Federal Rules to remove courts from that role. $^{\mathrm{ST}}$ This inefficiency, however, would be minor since the court would avoid involvement in all but unusual cases where the higher standard for discovery was met.

\section{Specific Situations in Which Information Gathering Is Proper}

It is not possible to enumerate completely the situations in which discovery directed at absent class members is proper. A few examples of specific situations, however, might help to clarify the range of responses available to a court exercising its sound discretion.

\section{Jurisdictional Information}

In the recent case of Zahn v. International Paper $\mathrm{Co}^{88}$ the Supreme Court held that a diversity suit cannot be maintained as a class action under Rule 23(b)(3) on behalf of unnamed plaintiffs whose claims do not meet the $\$ 10,000$ jurisdictional requirement even though the claims of named plaintiffs do. A suit must be dismissed as to any plaintiff who fails to satisfy the jurisdictional amount requirements. The clear implication of this decision is that information about a class member's claim is relevant to the jurisdiction of the court. A defendant's request for such information at the outset of the suit would clearly be proper, though there is no reason that a sanction greater than exclusion of silent members is necessary. A plaintiff who does not satisfy the jurisdictional requirement of the federal district courts is normally not prejudiced in pursuing his individual claim in another forum.

87. See Advisory Committe's Explanatory Statement Concerning Amendment of Discovery Rules, at 255-56 (Foundation Press ed. 1970); Fed. R. Civ. P. 33(a), Advisory Committee's Note (1970 Amendment), at 290 (Foundation Press ed. 1970).

88. 42 U.S.L.W. 4087 (U.S. Dec. 17, 1973). 


\section{Settlement Information}

Under Rule 23(e) all settlements must be approved by the court and notice of the proposed settlement given to all members of the class. Since the settlement would set a fixed sum available for satisfying all claims, the amount of individual claims before settlement is important to absent members of the class. Requests for information from absent class members might aid a court in discharging its obligation to see that the representative parties have fairly and adequately protected the interests of the class in compromising the action. ${ }^{89}$ Moreover, the concern expressed by commentators with respect to abuses in the settlement process ${ }^{90}$ suggests that a heightened judicial concern over the terms of settlement would be more than proper.

Information relevant to the fairness of a settlement might be gathered from a random sample of absent class members if notice to all members of the class is infeasible. Such information regarding prospective claims would give the court some indication of the appropriate aggregate settlement. The sanction of exclusion, however, might not be appropriate if the randomly selected class members failed to respond. The court could resort to the less onerous alternative of scaling down the aggregate settlement in proportion to the nonresponse rate.

\section{Conclusion}

No single procedure will adequately resolve all possible problems related to discovery of absent class members. Instead, courts need to remain flexible, resorting to different alternatives according to the circumstances. Ideally, courts will be able to develop management techniques that are consistent with the provisions and intent of the class action rule by using split trials, more representative parties, higher discovery standards, and milder penalties, thus enhancing the capacity of the class action device to adjudicate complex disputes efficiently and expeditiously.

89. Fed. R. Civ. P. 23(d)(2). See also Fed. R. Civ. P. 23(a)(4).

90. See, e.g., Handler, The Shift from Substantive to Procedural Innovations in Antitrust Suits-The Twenty-Third Annual Antitrust Review, 71 Colum. L. REv. 1, 5-12 (1971). 